\author{
Stanisław WOSIŃSKI ${ }^{1,5^{*}}$, Jan JURGA ${ }^{1}$, Zdzisław KRUCZYŃSKI $^{2}$ \\ Romuald GÓRSKI ${ }^{3}$, Krzysztof SOBIERALSKI ${ }^{4}$ and Marek SIWULSKI ${ }^{4}$
}

\title{
AN ESR STUDY OF FREE RADICALS SCAVENGING BY RED TEA
}

\author{
BADANIA METODĄ EPR WYMIATANIA WOLNYCH RODNIKÓW \\ PRZEZ CZERWONĄ HERBATE
}

\begin{abstract}
Herbal tea is known to exhibit the scavenging of free radicals responsible for cellular damage. We studied the effect of water treated with reverse osmotic filter equipped with a special dielectric ceramic composite on the antioxidant activity of red tea. Methanol solution of DPPH was added to the tea extract and the RT decay of DPPH free radicals was studied by ESR spectroscopy. Red tea brewed from tap water treated with the composite filter was found to exhibit higher radical scavenging efficiency in comparison with that of the tea brewed from tap water, mineral water and reverse osmosis water.
\end{abstract}

Keywords: free radicals, radical scavenging, ESR spectroscopy

A continuous increase in the level of ionizing radiation as well as the use of mechanical activation in food processing result in a symmetrical breaking of the chemical bonds and forms free radicals. Free radicals play an important role in many chemical and biological processes responsible for aging, tissue damage, and possibly some diseases. A free radical is an atom, a group of atoms or a molecule possessing one unpaired electron, which occupies an outer orbit [1]. Due to the spinning motion of the electron charge density the unpaired electron can be considered as a magnetic dipole with the electron spin related to the angular momentum of the electron. The electrons of atoms or molecules have a tendency

\footnotetext{
${ }^{1}$ Institute of Materials Technology, Poznan University of Technology, ul. Piotrowo 3, 60-965 Poznań, Poland, phone +486166523 94, fax +486166522 17, email: jan.jurga@ put.poznan.pl

${ }^{2}$ Faculty of Physics, Adam Mickiewicz University, ul. Umultowska 85, 61-614 Poznań, Poland, phone +486182952 24, fax +486182951 89, email: z.k@amu.edu.pl

${ }^{3}$ Department of Plant Protection Methods, Poznan University of Life Sciences, ul. Zgorzelecka 4, 60-198 Poznań, Poland, phone +48 6184663 36, email: rgorski@ up.poznan.pl

${ }^{4}$ Department of Vegetable Crops, Poznan University of Life Sciences, ul. Dąbrowskiego 159, 60-594 Poznań, Poland, phone +48 6184879 73, email: sobieralski@up.poznan.pl

${ }^{5}$ ADR Technology, ul. Żeleńskiego 18, 80-285 Gdansk, Poland, phone +48 5834195 41, fax +48 583419541 , email: s.wosinski@adrtechnology.eu

*Corresponding author: s.wosinski@ardtechnology.eu
} 
to form pairs with antiparallel spins because the magnetic dipoles of the paired electrons cancel each other out. The unpaired electrons exhibit a strong tendency to interact with other electrons and form electron pairs ie chemical bonds. Free radicals are very reactive and as their concentration rises continuously become more hazardous to human health. It has been assessed that the living organism is only able to neutralize about $35 \%$ of the exposed free radicals. Thus the simplest way is to supply antioxidants which are present in many foods and prevent free radicals from harming healthy tissue [2-4]. Green tea and Ginkgo biloba leaves are also known among natural antioxidants for their scavenging activity [5-8]. The antioxidant activity of Ginkgo biloba extract has been related to the presence of flavonoids and terpenoids [9-13]. The red tea (Rooibos) has also been reported to have high levels of antioxidants as aspalathin and nothofagin [14] and has become very popular and is consumed in many countries. Only recently, have results from studies of the effect of the purity of water on the antioxidant activity of green tea extract been published [15]. The authors studied the scavenging activity of green tea brewed from tap water, activated carbon adsorbed water, deionized water, distilled water, reverse osmosis water and ultra-pure water on nutritional components and scavenging effect of hydroxyl radicals $\left({ }^{\bullet} \mathrm{OH}\right)$ and superoxide radicals $\left({ }^{\bullet} \mathrm{O}_{2}^{-}\right)$. The concentration of the tea polyphenoles, caffeine, amin oacids and saccharides was determined by chromatographic analysis, whereas chemical analysis was used to characterize the scavenging effect on the free radicals. Though the heavy metal content was found to be correlated with those in the tested water the question of the importance of the synergistic activity of the tea chemical components (catechins, caffeine etc.) on human health and their effect on the free radical scavenging still remains.

Our studies are aimed at the question of whether the treatment of water, with a reverse osmotic ceramic composite filter, can improve the antioxidant activity of the red tea that it is brewed from. The filter consists of a conventional part based on reversal osmosis and is additionally equipped with a composite ceramic disc encased in a plastic housing (ADR $4^{\circledR}$ ). The composite ceramic disc has specially designed dielectric properties determined by its chemical composition and its microstructure. Small permanent magnets are embedded in the ceramic disc to create controlled magnetic field distribution. ESR was used to study the effect of free radical decay and the three types of water: tap water, tap water purified with the special ceramic filter and reverse osmosis water.

\section{Experimental}

\section{Preparation of extract}

We studied the ability of red tea brewed from different types of water to "remove" free radicals. The red tea infusion ( $1 \mathrm{~g}$ of leaves in $100 \mathrm{~cm}^{3}$ of boiled water) was brewed for $10 \mathrm{~min}$. Tap water purified with reverse osmotic filter equipped with a special ceramic composite, commonly used tap water, as well as, reverse osmosis and mineral water were used. The special ceramic composite consisted of a dielectric ceramic disc with small permanent magnets embedded in the ceramic (ADR- $\left.4^{\circledR}\right)$. The dielectric ceramic was based on aluminosilicates $\left(\sim 70\right.$ weight $\% \mathrm{SiO}_{2}, \sim 25 \% \mathrm{Al}_{2} \mathrm{O}_{3}$, and small additions of $\mathrm{P}_{2} \mathrm{O}_{5}, \mathrm{TiO}_{2}$, $\mathrm{Fe}_{2} \mathrm{O}_{3}, \mathrm{MgO}, \mathrm{CaO}, \mathrm{BaO}, \mathrm{Na}_{2} \mathrm{O}$ and $\mathrm{K}_{2} \mathrm{O}$ ) and the pellets were calcined at $1130^{\circ} \mathrm{C}$ 
at a pressure of $10 \mathrm{MPa}$. The infusion was stirred and poured through a paper filter after cooling to room temperature.

\section{Electron Spin Resonance measurements}

$0.25 \mathrm{~cm}^{3}$ of filtered tea infusion was mixed with $4 \mathrm{~cm}^{3}$ of DPPH/methanol solution ( 0.05 weight percent solution of $\alpha, \alpha^{\prime}$-diphenyl- $\beta$-picrylhydrazyl in $\mathrm{CH}_{3} \mathrm{OH}$ ) and to measure the decay of DPPH free radical concentration in the tea we used Electron Spin Resonance spectroscopy (ESR). The ESR signal of DPPH was recorded for duration of $10 \mathrm{~min}$ with a Bruker EMX spectrometer $(9.8 \mathrm{GHz})$ at room temperature. As the concentration of spins is proportional to the area under the ESR absorption curve the obtained derivative ESR signal was integrated digitally by computer. To check whether the decay of the ESR signal is due to the free radical decay we measured the drift of the Bruker EMX spectrometer (Fig. 1).

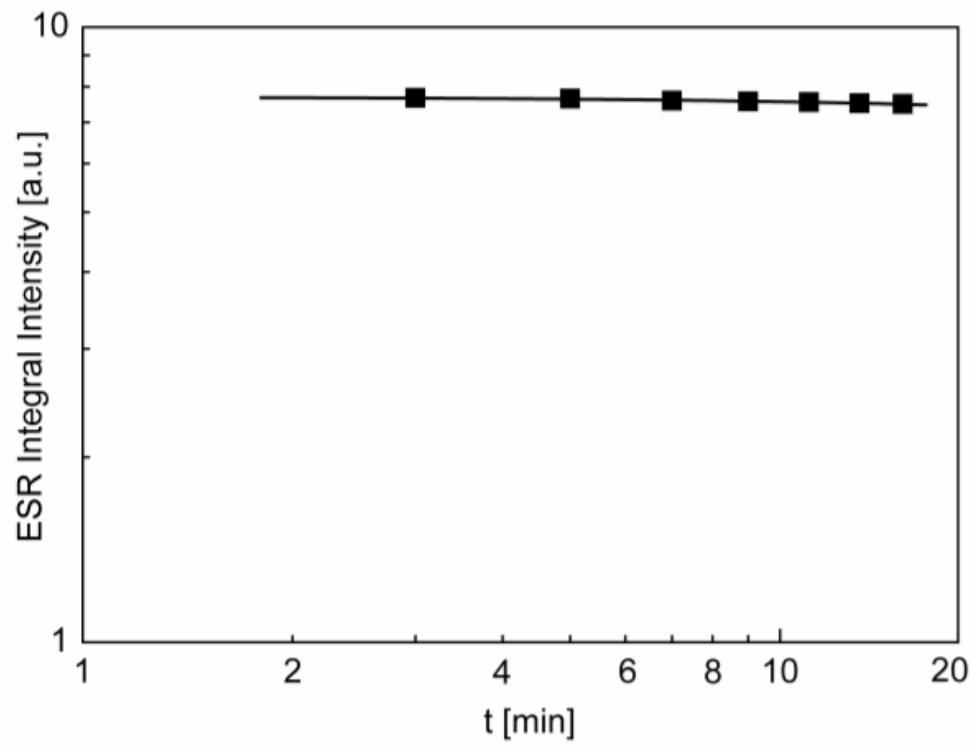

Fig. 1. Drift of the Bruker EMX spectrometer (ESR signal of DPPH)

\section{Results}

The radical scavenging activity of the red tea extract brewed from tap water treated with reverse osmotic ceramic composite filter, common tap water, as well as from mineral and reverse osmosis water was studied at room temperature. Figure 2 shows examples of the decay of the ESR spectra recorded for the mixture of DPPH/methanol and red tea brewed from the common tap water (2a) and tap water purified with a special composite ceramic filter (2b), respectively. In the experiments the first spectrum was recorded $1 \mathrm{~min}$ after preparation of the mixture and subsequent spectra were recorded after every $15 \mathrm{~s}$. 
a)

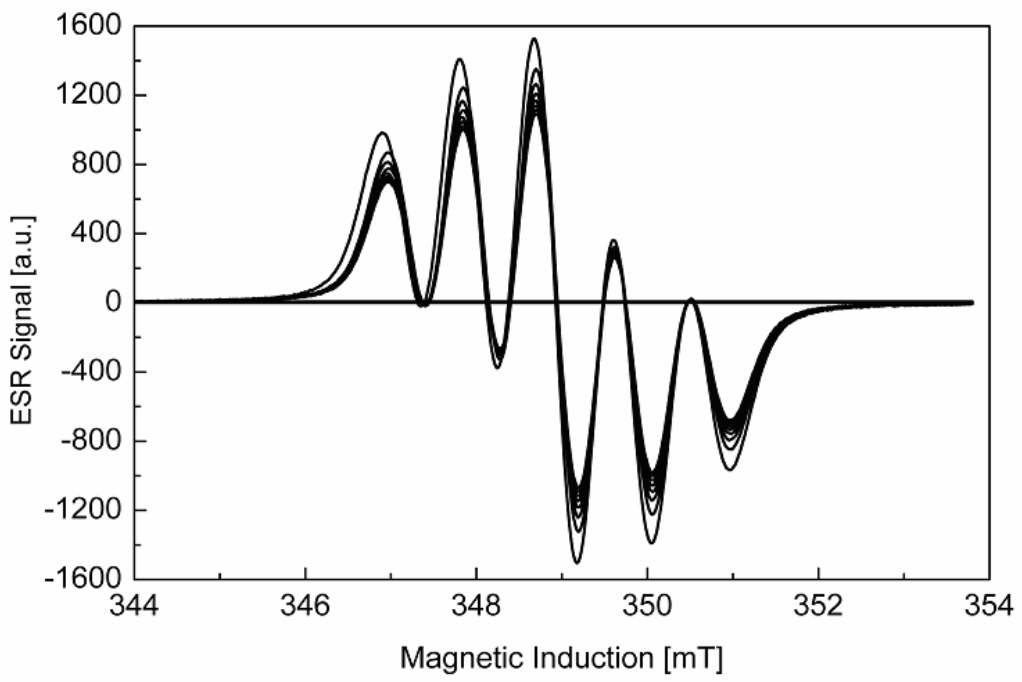

b)

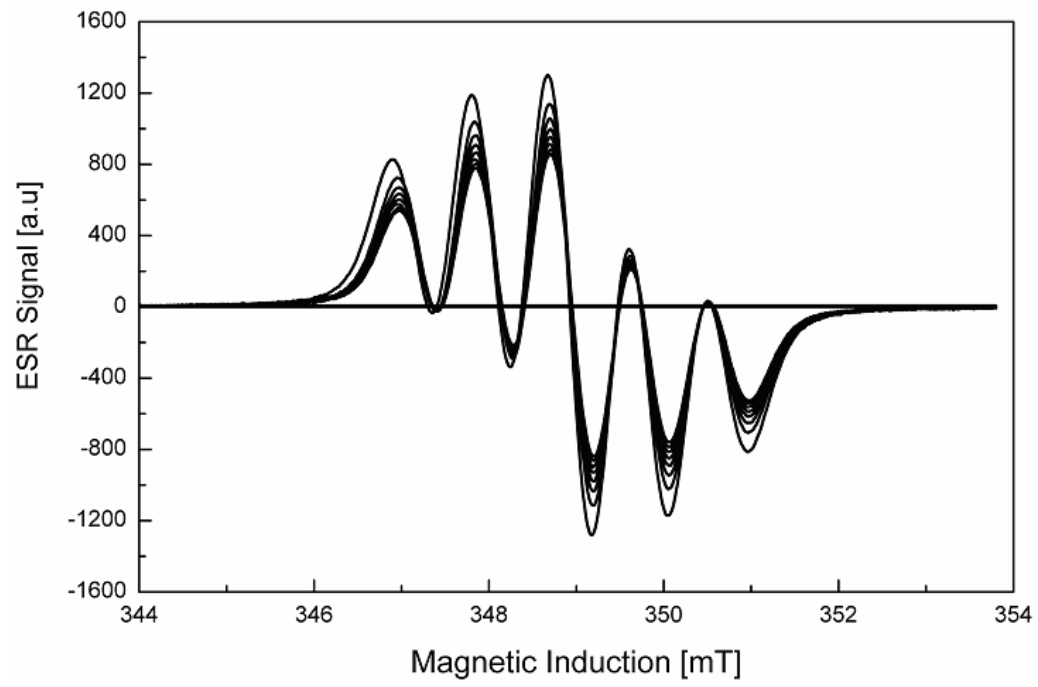

Fig. 2. ESR signal of the mixture of DPPH/methanol solution and red tea brewed from the tap water: the first spectrum was recorded $1 \mathrm{~min}$ after preparation and subsequent spectra were recorded after every $15 \mathrm{~s}$ (a) and the same sequence of the ESR signals for DPPH/methanol solution and red tea brewed from the tap water purified with the special ceramic composite filter (b)

Figure 3 shows the room temperature decay of the integrated ESR signal obtained for mixtures of a DPPH methanol standard solution and red tea brewed from various kinds of water: mineral water, reverse osmosis water, common tap water and reverse osmotic water with the composite ceramic filter. One can observe the highest decay rate of the DPPH free radicals in the solution prepared with tap water purified using the special reverse osmotic ceramic filter. Thus one can conclude that the tap water filtered is efficient in "free radical neutralization". 


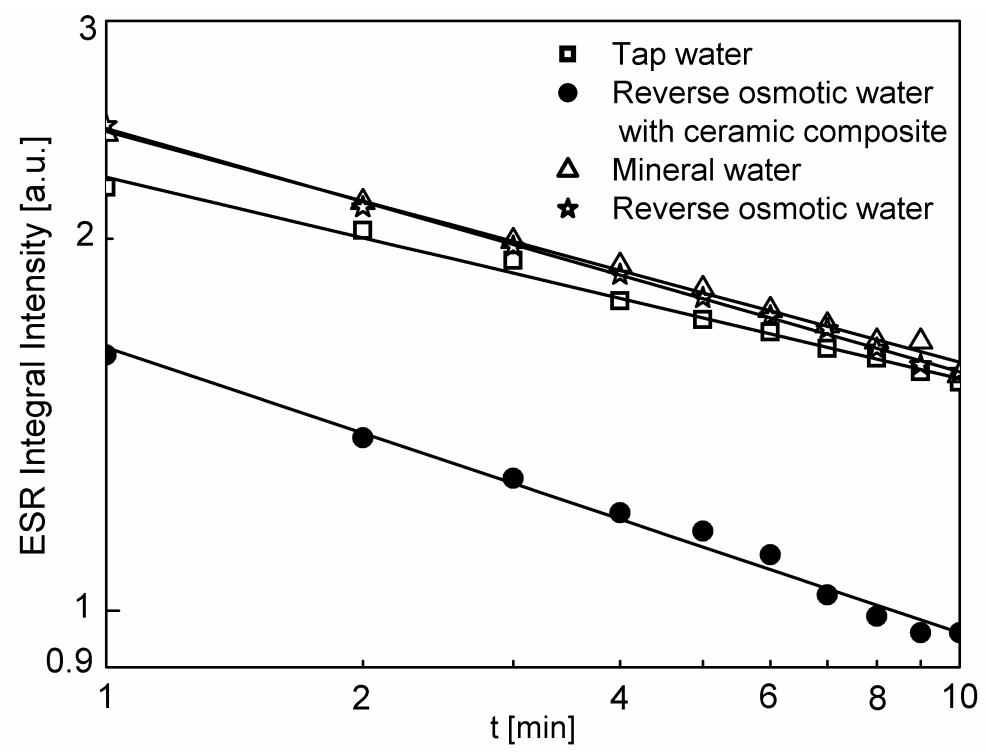

Fig. 3. Room temperature decay of the ESR signal of the mixture of DPPH/methanol solution and red tea brewed from various kinds of water

The decay of the free radical concentration can be described by:

$$
\mathrm{I}=\mathrm{at}^{-\mathrm{n}}
$$

where I denotes integral intensity of the ESR signal, $\mathrm{t}$ denotes the time, a and $\mathrm{n}$ are constants obtained from the experimental data fitting. The $\mathrm{a}$ and $\mathrm{n}$ constants obtained from fitting to eq. (1) the experimental data of free radical decay in tea brewed from various kinds of water are collected in Table 1. One can observe that the scavenging activity of the tea depends on the quality of water the tea has been brewed from. It appears that the highest decay rate of free radicals is observed in tea brewed from tap water purified with the special reverse osmotic composite ceramic filter.

The a and $\mathrm{n}$ values obtained from fitting the free radical decay in tea brewed from various kinds of water to eq. (1)

\begin{tabular}{|c|c|c|}
\hline Water the tea has been brewed from & a value & n value \\
\hline Tap water & $0.351 \pm 0.004$ & $0.163 \pm 0.006$ \\
\hline Mineral water & $0.388 \pm 0.004$ & $0.187 \pm 0.005$ \\
\hline Reverse osmosis water & $0.390 \pm 0.002$ & $0.197 \pm 0.003$ \\
\hline Reverse osmosis water with ceramic composite & $0.213 \pm 0.007$ & $0.231 \pm 0.009$ \\
\hline
\end{tabular}

As it has been reported earlier that the extraction efficiency of major catechins from green tea depends mainly on the tea-to-water ratio and the effect of the $\mathrm{pH}$ value of water appears at low tea concentration only [16] we did not determine the water quality parameters, the tea has been brewed from, ie we did not measure the $\mathrm{pH}$ value, the ion content and electric conductivity. In all experiments we have provided the same infusion 
conditions: the same temperature, infusion time, tea-to-water ratio and particle size of tea leaves and therefore we consider having the same extraction efficiency. It should be however, noted that the quality of tap water, though being determined by national standards, vary in time therefore, we tested whether the scavenging activity of the tea brewed from filtered tap water drawn at different time is higher than that of non-filtered. The mixtures of DPPH/methanol standard solution and red tea brewed from the tap water non-filtered and filtered were prepared using the testing standard described above. Figure 4 shows an example of the room temperature decay of the integral intensity of the ESR signal of the mixture of DPPH/methanol standard solution and red tea brewed from tap water and filtered tap water sampled at the same time from the water line. We repeated the experiment three times. It should be noted that the sensitivity of ESR spectrometer in the experiments was different than that in the experiment the results of which are shown in Figures 1-3. The decay of the integral intensity I of ESR signal shown in Figure 4 and in the other two experiments can be approximated by equation (1) and the fitting parameters a and $\mathrm{n}$ for various experiments are presented in Table 2.

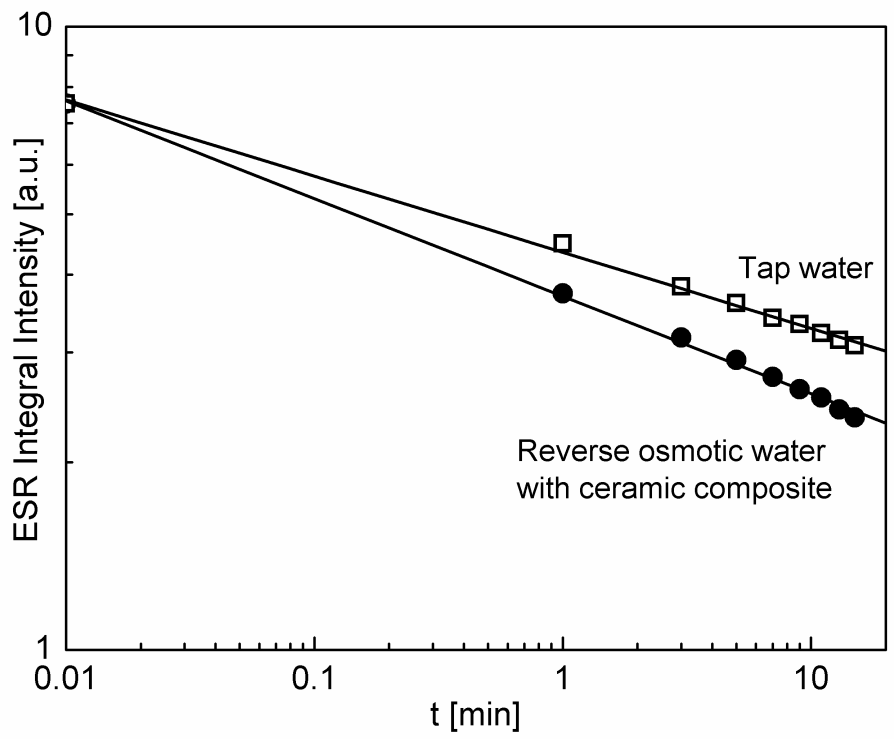

Fig. 4. An example of room temperature decay of the ESR signal of the mixture of DPPH/methanol solution and red tea brewed from tap water and reverse osmotic water with the special ceramic composite filter; the samples were drawn from the city water supply at the same time

Table 2

The a and $\mathrm{n}$ values obtained from fitting the free radical decay in tea brewed from tap and filtered water sampled at the same time to eq. (1)

\begin{tabular}{|c|c|c|c|}
\hline & Experiment I & Experiment II & Experiment III \\
\hline Tap water & $\mathrm{a}=0.565 \pm 0.006$ & $\mathrm{a}=0.638 \pm 0.003$ & $\mathrm{a}=0.652 \pm 0.002$ \\
& $\mathrm{n}=0.151 \pm 0.005$ & $\mathrm{n}=0.122 \pm 0.002$ & $\mathrm{n}=0.110 \pm 0.002$ \\
\hline Reverse osmosis water with & $\mathrm{a}=0.496 \pm 0.005$ & $\mathrm{a}=0.568 \pm 0.003$ & $\mathrm{a}=0.593 \pm 0.004$ \\
ceramic composite & $\mathrm{n}=0.190 \pm 0.005$ & $\mathrm{n}=0.157 \pm 0.002$ & $\mathrm{n}=0.147 \pm 0.003$ \\
\hline
\end{tabular}


The decay of the ESR integral intensity $I_{1}$ measured for the DPPH solution mixture with red tea brewed from the tap water reads: $I_{1}=a_{1} \cdot t^{-n_{1}}$ and the respective intensity $I_{2}$ obtained for the DPPH solution mixed with red tea brewed from filtered tap water is $\mathrm{I}_{2}=\mathrm{a}_{2} \cdot \mathrm{t}^{-\mathrm{n}_{2}}$. The ratio of the intensities reads:

$$
\frac{I_{2}}{I_{1}}=c \cdot t^{-\left(n_{2}-n_{1}\right)}
$$

The calculations yield $\mathrm{n}_{2}-\mathrm{n}_{1}=0.039 \pm 0.005$ for the measurements in Experiment No. I, $\mathrm{n}_{2}-\mathrm{n}_{1}=0.035 \pm 0.002$ for the Experiment No. II and $\mathrm{n}_{2}-\mathrm{n}_{1}=0.037 \pm 0.003$ for the Experiment No. III. It appears that the difference $n_{2}-n_{1}$ does not differ in the three experiments within the measuring uncertainty.

\section{Discussion and conclusions}

It should be considered that at nanoscopic level water is a heterogeneous liquid which consists of: isolated $\mathrm{H}_{2} \mathrm{O}$ molecules, molecules linked with hydrogen bonds and $\mathrm{H}_{3} \mathrm{O}^{+}$and $\mathrm{OH}^{-}$ions [17]. In its liquid state water contains randomly distributed clusters of polar molecules linked by hydrogen bonds [18, 19], which can be affected both by electric and magnetic fields. It has been observed that static or low-frequency electric fields cause an alignment of polar water molecules. Even partial alignments of the water molecules result in a bending or breaking of the existing hydrogen bonds. Static magnetic fields, however, result in the opposite effect causing an increase in hydrogen bond strength in the structure of the liquid [20]. The special ceramic composite placed in the reverse osmotic filter exhibits high dielectric absorption and shields the electric field in the frequency range from $\sim 100 \mathrm{mHz}$ to $1 \mathrm{MHz}$ [21] and thus precludes the weakening of the hydrogen bond strength in water. Permanent magnets, embedded in the ceramics, stabilize the hydrogen bond ordering in water amplifying the electric field shielding effect of the ceramic composite.

Antioxidants are involved in the prevention of cellular damage responsible for cancer, aging, and a variety of diseases therefore there is great interest in a search for materials that can help to neutralize free radicals. As various herbal teas were found to prevent against free radical damage there arose the question whether their scavenging activity may be enhanced in a simple way. To brew the red tea we used tap water purified using reverse osmotic filter equipped with special composite ceramics and studied the scavenging activity of DPPH radicals in the tea infusion mixture. The scavenging activity was compared with that of red tea brewed with common tap water as well as, reverse osmosis water and mineral water. The ESR measurements show that the highest rate of free radical decay was the red tea brewed from tap water treated with reverse osmotic filter equipped with special composite ceramics. Thus red tea brewed with tap water treated with reverse osmotic composite ceramic filter can be recommended as a simple efficient scavenger helping to prevent cell and tissue damage that can result in cellular damage and disease.

\section{References}

[1] Ranby B, Rabek JF. ESR Spectroscopy in Polymer Research. Berlin: Springer Verlag; 1977.

[2] Facino MR, Carini M, Aldini G, Piccone M, Morazzoni P, Bombardelli E. Antioxidant profile of soy standardized extract. In: Joint Meeting 1999 - Book Abstracts '2000 Years of Natural Products Research'. Amsterdam; 1999. 
[3] Štajner D, De Marino NM, Conadovi-Brunet J. Antioxidant and scavenger activities of cultivated wild Allium species. In: Joint Meeting 1999 - Book Abstracts '2000 Years of Natural Products Research'. Amsterdam; 1999.

[4] Bahorun T, Trotin F, Pommery J, Vasseur J, Pinkas M. Planta Med. 1994;60(4):323-328. DOI: $10.1055 / \mathrm{s}-2006-959493$.

[5] Vinson JA, Dabbagh YA, Serry MM, Jang J. J Agric Food Chem. 1995;43(11):2800-2802. DOI: $10.1021 / \mathrm{jf00059a005.}$

[6] Joyeux M, Lobstein A, Anton R, Mortier F. Planta Med. 1995;61(2):126-129. DOI: $10.1055 / \mathrm{s}-2006-958030$.

[7] Oh JH, Kim EH, Kim JL, Moon YI, Kang YH, Kang JS. J Korean Soc Food Sci Nutr. 2004;33(7):1079-1084.

[8] Doss MX, Potta SP, Hescheler J, Sachinidis A. J Nutr Biochem. 2005;16(5):259-266. DOI:10.1016/j.jnutbio.2004.11.003.

[9] Ellnain-Wojtaszek M. Acta Polon Pharm. 1997;54:225-228.

[10] Ellnain-Wojtaszek M, Zgórka G. J Liq Chromatog Relat Technol. 1999;22:1457-1471. DOI: $10.1081 /$ JLC-100101744.

[11] Gadow A, Joubert E, Hansmann CF. J Agric Food Chem. 1997;45(3):632-638. DOI: 10.1021/jf960281n.

[12] Vinson JA, Jang J, Dabbagh YA, Serry MM, Cai S. J Agric Food Chem. 1995;43(11):2798-2799. DOI: 10.1021/jf00059a004.

[13] Ellnain-Wojtaszek M, Kruczyński Z, Kasprzak J. Fitoterapia. 2003;74:1-6.

[14] Bramanti L, Minoggio M, Gardana C, Simonetti P, Mauri P, Pietta P. J Agric Food Chem. 2002;50(20):5513-5519; DOI: 10.1021/jf025697h.

[15] Danrong Z, Yuqiong C, Dejiang N. Food Chem. 2009;113:110-114. DOI: 10.1016/j.foodchem.2008.07.033.

[16] Yoshida Y, Kiso M, Goto T. Food Chem. 1999;67:429-433. DOI: 10.1016/S0308-8146(99)00148-X.

[17] Needham P. Stud Histor Philosoph Sci. 2008;39:66-77. DOI: 10.1016/j.shpsa.2007.11.005.

[18] Suresh SJ, Naik VM, J Chem Phys. 2000;113(21):9727-9732. DOI: 10.1063/1.1320822.

[19] Hakala M, Nygård K, Manninen S, Huitari S, Buslaps T, Nilsson A, et al. J Chem Phys. 2006:125:084504-1-7. DOI: 10.1063/1.2273627.

[20] Ozeki S, Wakai C, Ono S. J Phys Chem. 1991;95:9401-9403. DOI: 10.1063/1.461168.

[21] Wosiński S. Effect of Composition and Processing Conditions of Ceramic and Polymer Composites on the Electric Field Shielding Ability [PhD Thesis]. Poznan: Poznan University of Technology; 2010.

\title{
BADANIA METODĄ EPR WYMIATANIA WOLNYCH RODNIKÓW PRZEZ CZERWONĄ HERBATE
}

\author{
${ }^{1}$ Instytut Technologii Materiałów, Politechnika Poznańska \\ ${ }^{2}$ Wydział Fizyki, Uniwersytet im. Adama Mickiewicza w Poznaniu \\ ${ }^{3}$ Katedra Metod Ochrony Roślin, Uniwersytet Przyrodniczy w Poznaniu \\ ${ }^{4}$ Katedra Warzywnictwa, Uniwersytet Przyrodniczy w Poznaniu \\ ${ }^{5}$ ADR Technology
}

\begin{abstract}
Abstrakt: Herbata ziołowa jest znana z własności wymiatania rodników odpowiedzialnych za uszkodzenia komórkowe. Zbadano wpływ wody poddanej filtracji metodą odwróconej osmozy z zastosowaniem dielektrycznego kompozytu ceramicznego na aktywność antyoksydacyjną czerwonej herbaty. Do ekstraktu herbaty dodawano metanolowego roztworu DPPH i badano metodą EPR zanik czasowy wolnych rodników DPPH. Czerwona herbata zaparzana na wodzie wodociągowej traktowanej filtrem kompozytowym wykazywała większą zdolność wymiatania rodników w porównaniu z herbatą zaparzaną na wodzie wodociągowej, wodzie mineralnej i wodzie z odwróconej osmozy.
\end{abstract}

Słowa kluczowe: wolne rodniki, zdolność wymiatania, EPR 